\title{
Relationship of Herbicidal Activity of Soil-Applied Mefenacet to its Concentration in Soil Water and Adsorption in Soil*
}

\author{
Katsuichiro Kobayashi**, Naoki Nakamura***, Ie Sung Shim** \\ and Shizuo Nagatsuka**
}

\begin{abstract}
The phytotoxic activity of mefenacet [2-(benzothiazol-2-yloxy)-Nmethylacetanilide] mixed with soil on rice (Oryza sativa cv. Nipponbare) was much greater in Ryugasaki paddy soil than in Yawara paddy soil. The soil used for bioassay was centrifuged to separate it into plant available soil water and centrifuged-soil. The phytotoxic activity of mefenacet was well correlated with its concentration in soil water but not with the amount in the soil applied with the herbicide. The amount of adsorption in solid phase in soil was much more in Yawara paddy soil than in Ryugasaki paddy soil, whereas the amounts of adsorption in soil organic matter were identical. The proposed metabolites of mefenacet showed no phytotoxic activity on rice. It was suggested that the herbicidal activity of soil applied with mefenacet was induced by the herbicide's concentration in plant available soil water which was primarily determined by its adsorption in soil, mostly in soil organic matter.
\end{abstract}

* Parts of this work were reported at the 34th annual meeting of the Weed Science Society of Japan in April, 1995, and the 15th Asian-Pacific Weed Science Society Conference in July, 1995.

** Institute of Applied Biochemistry, University of Tsukuba, Tsukuba, Ibaraki 305, Japan.

*** Doctoral Program in Agricultural Sciences, University of Tsukuba, Tsukuba, Ibaraki 305, Japan.

(Received January 8, 1996)
Key words: mefenacet, herbicide in soil water, herbicidal activity, adsorption, soil organic matter

\section{Introduction}

Mefenacet [2-(benzothiazol-2-yloxy)-Nmethylacetanilide], is a herbicide for annual gramineous and some dicotyledonous weeds which it controls selectively by so-called "placement selectivity" in a transplanted rice field ${ }^{1,2,10)}$. Our previous study ${ }^{8)}$ revealed that the herbicidal activity of mefenacet applied to soil was well correlated with the concentration of water-soluble ingredients, and similar findings were also reported for butachlor [N-(butoxymethyl)-2-chloro-2', $6^{\prime}$-diethylacetanilide $]^{6)}$, pretilachlor $\left[2-\right.$ chloro $-2^{\prime}, 6^{\prime}-$ diethyl- $N-(2-\text { propoxyethyl) acetanilide }]^{6)}$, metolachlor [2-chloro-2'-ethyl-N-(2-methoxy-1-methylethyl)- $6^{\prime}$-methylacetanilide $]^{9)}$ and pendimethalin[ $N$-(1-ethylpropyl)-2, 6dinitro-3, 4-xylidine $]^{7}$. In these studies, however, the water-soluble ingredient was extracted with added water, suggesting that the concentration contained in the waterextract might not reflect the actual concentration existing in soil water itself in soil to which herbicide had been applied. Recently, we demonstrated ${ }^{3,5)}$ that the herbicidal activity of thenylchlor [2-chloro- $N$-(3-methoxy2-thienyl)methyl-2', 6'-dimethylacetanilide] in soil was well correlated with the concen- 
tration in soil water but not with the total amount in the herbicide-applied soil, and suggested that the phytotoxic activity of herbicide applied to soil was substantially induced by its concentration in plant available soil water.

This study was undertaken to clarify the relationship of herbicidal activity of mefenacet in soil to its concentration in plant available soil water and its adsorption in soil.

\section{Materials and Methods}

\section{Soil materials and mefenacet application}

Yawara (light clay, organic carbon content $2.41 \%$ ) and Ryugasaki (sandy loam, organic carbon content $0.43 \%$ ) paddy soils ${ }^{5)}$ were used in the experiments. Two hundred grams of air-dried soil was put into $500 \mathrm{ml}$ of aqueous mefenacet solution containing $0.5 \%$ acetonitrile at various designated concentrations, and mixed thoroughly with a kitchen stirrer in a beaker. The prepared-soil was then placed in a plastic pot $(5 \mathrm{~cm}$ in diameter and $4 \mathrm{~cm}$ in height) with holes in the bottom and allowed to stand for 10 hours to reach maximum water capacity by removing the gravitational water. This soil is hereinafter referred to as applied-soil.

\section{Plant materials and bioassay}

Rice (Oryza sativa cv. Nipponbare) was used as a test plant because it was found to be highly responsive to mefenacet in our preliminary experiment. Seeds of rice were soaked in distilled water for one day, and then germinated in a petri dish at $25^{\circ} \mathrm{C}$. In soil culture, the germinated seeds were planted and covered with the applied-soil in the plastic pot. In water culture, the germinated seeds were placed in $2.5 \mathrm{ml}$ solution of mefenacet, 2-benzothiazolyloxy acetic acid (BTA), or $2(3 \mathrm{H})$-benzothiazolone (HBT) at various designated concentrations with $0.5 \%$ acetonitrile in a vial $(2 \mathrm{~cm}$ in diameter and 4.5 $\mathrm{cm}$ in height). In soil water culture, the seeds were grown in the available soil water centrifuged from the applied-soil as described later, and the bioassay was carried out in the same way as in water culture. The plants in the vials were placed in an incubator $\left(25^{\circ} \mathrm{C}, 14 \mathrm{hr}\right.$.-illumination at about $70 \mu \mathrm{E} / \mathrm{m}^{2} / \mathrm{sec}$ ) for 3 days, and the shoot length was measured. All experiments were carried out with three replications.

\section{Extraction and determination of mefenacet in soil}

The applied-soil was centrifuged with double tubes at $13,000 \times \mathrm{g}$ for $40 \mathrm{~min}^{3,5)}$ to separate it into plant available soil water ${ }^{4)}$ in the bottom of the outer tube (soil water) and the soil remaining in the inner tube (centrifugedsoil). The soil water was pipetted off and immediately prepared for high performance liquid chromatographic (HPLC) analysis. Mefenacet in the centrifuged-soil was extracted with acetonitrile and the extracted solution was prepared for HPLC analysis. The amount of mefenacet was determined by HPLC (Shimadzu 6 A liquid chromatograph) equipped with a Tosoh ODS-80Tm analytical column (a $150 \times 4.6 \mathrm{~mm}$ i.d.), a Shimadzu UV spectrophotometric detector operating at 254 $\mathrm{nm}$ and a chromatocorder. The mobile phase $(1 \mathrm{ml} / \mathrm{min})$ was composed of acetonitrile, water and acetic acid (50:50:2, $\mathrm{v} / \mathrm{v})$. The detectable limit of mefenacet was $0.001 \mathrm{ppm}$, and the recoveries from the centrifuged-soil and the soil water were over 93\%. The amount of mefenacet adsorbed in centrifuged-soil was calculated as that in the solid phase in the centrifuged-soil, in which the water content was $17.8 \%$ and $11.7 \%$ for Yawara paddy soil and Ryugasaki paddy soil, respectively. The calculation was made as follows : [amount adsorbed in solid phase] = [total amount in centrifuged-soil] - [amount in soil water in the centrifuged-soil], where 
the concentration in water in the centrifugedsoil was regarded as the same as in the available soil water. The amount adsorbed in soil organic matter was calculated as follows : [amount adsorbed in soil organic matter $]=$ [amount adsorbed in solid phase $] /$ [organic carbon content].

\section{Results and Discussion}

The growth of rice in the soil applied with mefenacet solution was much greater in Yawara paddy soil than in Ryugasaki paddy soil, indicating that the phytotoxic activity of mefenacet applied to the soils was more remarkable in the latter (Fig. 1). The relationship between the plant growth and the mefenacet concentration determined in the applied-soil or in soil water at planting is shown in Fig. 2. The results demonstrated that the phytotoxic activity of mefenacet in soil water was identical in the two soils, whereas the phytotoxic activity in appliedsoil differed greatly between them. In water culture, the growth of rice in mefenacet solution directly prepared was suppressed to a similar extent to that in the soil water from both paddy soils which had been previously applied with the herbicide (Fig. 3). Neither BTA nor HBT, the postulated metabolites of

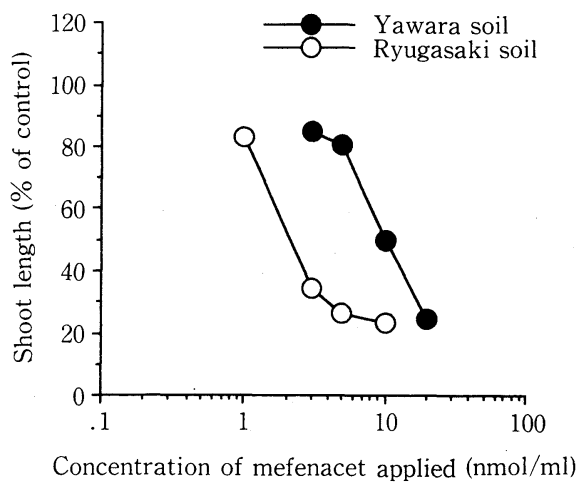

Fig. 1. Growth of rice in Yawara and Ryugasaki paddy soils applied with various concentrations of mefenacet solution.

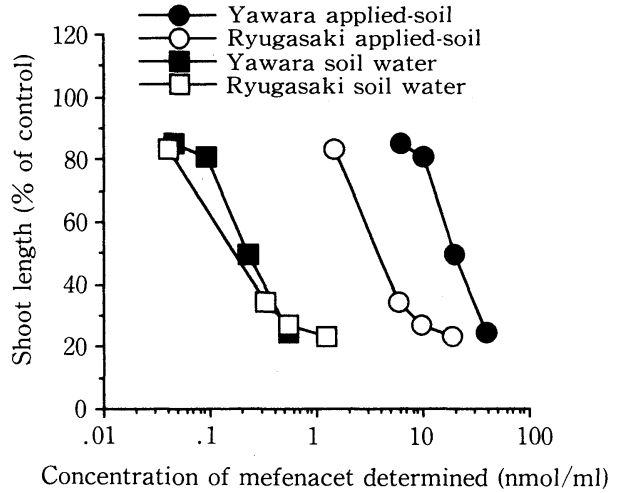

Fig. 2. Relationship of rice growth to the concentration of mefenacet determined in soil water or applied soil.

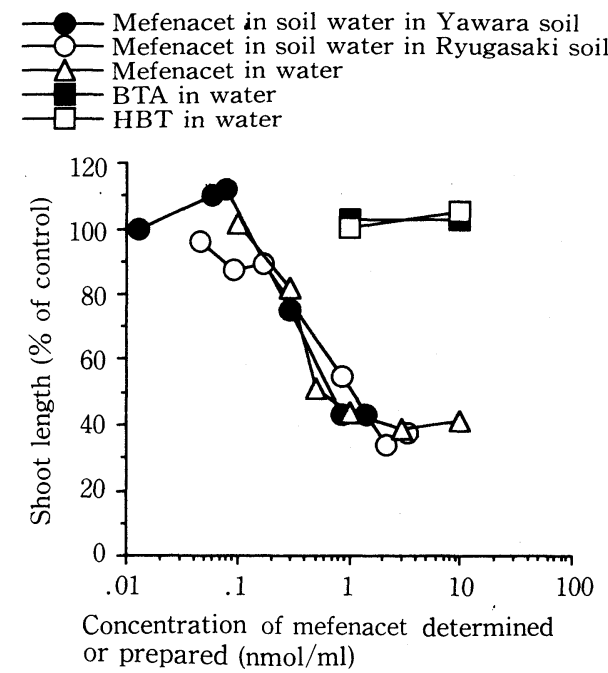

Fig. 3. Growth of rice in soil water and in distilled water containing mefenacet and the proposed metabolites at various concentrations.

mefenacet in soil ${ }^{10)}$, had phytotoxic activity on the growth of rice. These results suggested that the herbicidal activity of mefenacet applied to soil depended on its concentration in soil water but not on the amount in the applied-soil.

Adsorption of mefenacet in the solid phase and in the organic matter in the applied-soil are shown in Fig. 4. The adsorption in the solid phase, determined as the amount contained in solid phase in the centrifuged- 

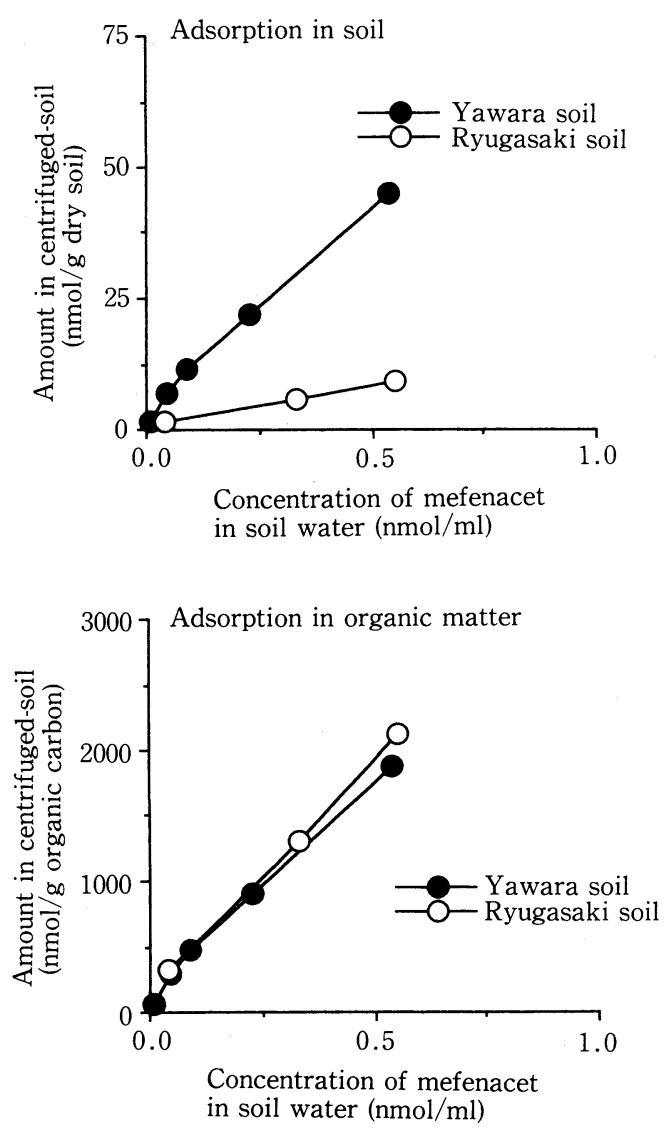

Fig. 4. Adsorption of mefenacet in solid phase and in organic matter in Yawara and Ryugasaki paddy soils.

soil from the soil which had actually been used for the bioassay, was much greater in Yawara paddy soil than in Ryugasaki paddy soil, whereas the adsorption in the organic matter of the former was almost same as that of the latter. This indicated that the adsorption of mefenacet in soil mostly depended on the organic matter content in soil.

The results obtained in this study demonstrated that the greater phytotoxic activity of mefenacet on the growth of rice in Ryugasaki paddy soil than in Yawara paddy soil was correlated well to the higher concentration in soil water in the former, and that the adsorption in soil was dominated substan- tially by the organic matter content in soil in a similar manner to thenylchlor ${ }^{3,5)}$. It is important to emphasize that determining the amount adsorbed in solid phase and the concentration in soil water in the soil actually used for bioassay is useful in clarifying the direct relationship between the phytotoxic activity of soil-applied herbicide and the performance of that herbicide in soil. It thus can be concluded that the herbicidal activity of soil-applied mefenacet is substantially induced by the concentration in plant available soil water, as true with thenylchlor ${ }^{3,5)}$, and that the amount of adsorption of herbicide in soil greatly dominates the concentration in soil water. This study fortifies our suggestion in previous reports ${ }^{3,5)}$ that the herbicidal activity of soil-applied herbicide is induced substantially by its concentration in plant available soil water. Further studies are necessary to clarify the relationship of herbicide concentration in soil water to the adsorption mechanism and the metabolism in soil.

Acknowledgements: We are grateful to Nihon Bayer Agrochem Co., Ltd. for the gift of mefenacet and related compounds. This work was supported in part by a Grant-inAid for Scientific Research from the Japan Society of the Promotion of Science.

\section{References}

1) Aya, M., K. Yasui, K. Kurihara, A. Kamochi and L. Eue 1987. Mefenacet-a new paddy herbicide. Proc. 10th Asian-Pacific Weed Sci. Soc. Conf. 567-573.

2) Fedtke, C. 1987. Physiological activity spectra of existing graminicides and the new herbicide 2-(2-benzothiazolyl-oxy)- $N$-methyl- $N$ phenylacetamide (mefenacet). Weed Res., 27, 221-228.

3) Kobayashi, K., M. Onoe and H. Sugiyama 1994. Thenylchlor concentration in soil water and its herbicidal activity. Weed Res., Japan 39, 160- 
164.

4) Marshall, T.J. and J.W.Holmes 1988. Soil Physics. Cambridge University Press, Cambridge, pp. 32-56.

5) Onoe, M., D.J. Lee, K. Kobayashi and H. Sugiyama 1995. Herbicidal activity of soilapplied thenylchlor and its mobility in two paddy soils. Weed Res., Japan 40, 75-79.

6) Sugiyama, H., K. Komamiya and K. Kobayashi 1990. Butachlor and pretilachlor concentration in paddy soils in relation to phytotoxicity to rice plant. Weed Res., Japan 35, 116 121. (in Japanese with English summary)

7) Sugiyama, H., K. Komamiya and K. Kobayashi 1990. Changes in the concentration of residues of pendimethalin applied to soil and effect on plant growth. Weed Res., Japan 35, 122-128. (in Japanese with English summary)

8) Sugiyama, H., K. Komamiya and K. Kobayashi 1990. Mefenacet concentration in the paddy soil and its phytotoxicity to rice plant. Weed Res., Japan 35, 180-182. (in Japanese)

9) Sugiyama, H. and K. Kobayashi 1993. Herbicidal activity and residual state of metolachlor in upland soil. Weed Res., Japan 38, 300306.

10)* Yasui, K. 1986. Hinokuroa (mefenacet) - a new herbicide for rice paddy field - Pesticide Res. 33, 30-52. (in Japanese)

* Translated from Japanese by the present authors

\section{土壤処理メフェナセットの殺草活性と土壌水中 濃度および土埪吸着との関係}

小林勝一郎*・中村直紀**・沈 利星*・永塚鎮男*

\section{摘 要}

谷和原および竜ケ崎水田土壌を供試し，土壊に処 理したメフェナセット [2-(benzothiazol-2yloxy) $-N$-methylacetanilide] の生育抑制効果と 土壤水中濃度との関係を検討し，次いで土壤水中濃 度と土壌吸着との関係について検討した。

上記土垬に本剤の水溶液を添加，混和し，イネ (Oryza sativa cv. Nipponbare) を供試して本剤の 生育抑制効果を調べた結果，谷和原土壌(軽埴土)に 比べ竜ケ崎土壌（砂壌土）での生育が強く抑制され た (Fig. 1)。生育試験に供試した土壌を二重遠心管 を用いて遠心分離し，本剤の存在量を有効水と遠心

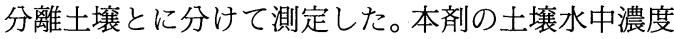

* 筑波大学 応用生物化学系

** 筑波大学 農学研究科
は竜ケ崎土袞で高く，また生育抑制効果は土㙵水中 濃度が同じであれば，両土壤でほぼ一致したが，処 理土壌に含まれる全量とは関連がなかった（Fig， 2)。本剂を処理した土壤から採取した土壊水中濃度 と蒸留水で直接調整した本剤の水溶液における濃 度が同じであれば，生育抑制効果は同じであった (Fig. 3)。また, 生育試験に用いた土壤を遠心分離し て得られた土㙴水および固相における本剤の実測 量により求めた本剤の固相への吸着は, 竜ケ崎土㗧 に比べ谷和原土壤で高かったが，同様にして求めた 土壤有機物への吸着量は, 両土壤間での差異は極め て少なく(Fig. 4), 本剤の土猿吸着はほとんど有機 物に依存していることが示された。

これらの結果から，土壤に施用したメフェナセッ 卜の殺草活性は, 主として土壌との吸着, 特に土壤 中の有機物との吸着によって支配される本剤の土 壌水中濃度に依存して発現すると考えられる。

キーワード : メフェナセット, 土壤水中除草剤濃 度, 殺草活性, 土壊吸着, 土袞有機物 